\title{
PENGEMBANGAN SISTEM TERINTEGRASI UNTUK PANDUAN PARIWISATA BERBASIS MOBILE SEBAGAI DAYA DUKUNG PENINGKATAN PARIWISATA DI KABUPATEN BULELENG
}

\author{
I Nengah Suparta ${ }^{1}$, Ketut Agustini ${ }^{2}$, I Made Gede Sunarya ${ }^{3}$, I Made Agus Wirawan ${ }^{4}$ \\ ${ }^{1} J u r u s a n$ Pendidikan Matematika, Fakultas MIPA \\ 2,3,4 Jurusan Pendidikan Teknik Informatika, Fakultas Teknik dan Kejuruan \\ Universitas Pendidikan Ganesha \\ e-mail : isuparta@yahoo.com, eghee2006@Gmail.com, \\ dek naya@yahoo.com imade.aguswirawan@gmail.com
}

\begin{abstract}
Abstrak
Penelitian ini bertujuan untuk mengembangkan sebuah sistem yang terintegrasi untuk panduan pariwisata berbasis mobile sebagai daya dukung peningkatan pariwisata di Kabupaten Buleleng. Hasil lebih luas terhadap produk yang dihasilkan dapat dimanfaatkan secara lebih luas oleh para wisatawan maupun para pelaku pariwisata lainnya dalam rangka mendukung percepatan pembangunan dan perluasan ekonomi khususnya di Kabupaten Buleleng. Metode penelitian menggunakan Riset\&Development yang dilengkapi metode khusus pengembangan perangkat lunak System Development Life Cycle dengan model waterfall. Hasil pengembangan dan pengujian fungsional sistem terintegrasi panduan pariwisata berbasis mobile yang telah dilakukan, menunjukkan bahwa Aplikasi sistem terintegrasi panduan pariwisata berbasis mobile dapat menjalankan fungsionalitas yang dibutuhkan dalam mencari info-info daerah pariwisata di Kabupaten Buleleng secara detail, beserta fasilitas umum terdekatnya.
\end{abstract}

Kata Kunci : Pengembangan, sistem terintegrasi, panduan pariwisata, berbasis mobile, pariwisata Kabupaten Buleleng

\begin{abstract}
This study aims to develop an integrated system to guide mobile-based tourism as a carrying capacity increased tourism Buleleng regency. The results of a wider range of products produced can be used more widely by tourists and other tourism actors in order to support the accelerated development and economic expansion, especially in Buleleng regency. The research method used for Research \& Development which include specific methods of software development System Development Life Cycle with the waterfall model. The results of development and functional testing of the integrated system based mobile tourism guide that has been done, showing that the application of integrated system-based mobile tourism guide functionality required to run the info-seeking tourist areas in Buleleng regency in detail, along with the nearest public facility.
\end{abstract}

Keywords: development, systems integration, tourism guides, mobile-based, tourism Buleleng regency 


\section{PENDAHULUAN}

Timpangnya pendapatan antara Bali Selatan dan Bali Utara yang tampak mencolok terlihat dari terfokusnya pengembangan pariwisata di Bali Selatan. Para wisatawan lebih mengenal daerah wisata Kuta di Kabupaten Badung dan Tanah Lot di Kabupaten Tabanan. Padahal Bali utara tidak kalah indahnya dengan daerah lain di Bali. Wilayahnya yang masih tradisional dan menyatu dengan alam dan kebudayaan yang ada memberikan suatu daya tarik tersendiri yang tidak dapat diperoleh wisatawan di daerah lain. Banyaknya usaha konservasi di berbagai daerah wisata di Bali Utara memberikan suatu nilai tambah akan keunikan yang membanggakan. Namun sangat disayangkan jika semua keindahan itu tidak dapat dinikmati oleh wisatawan yang datang ke Bali. Hal ini disebabkan karena masih kurangnya upaya pemerintah Bali untuk mempromosikan berbagai potensi wisata yang ada di wilayah Bali Utara agar dapat lebih siap menerima calon wisatawan baru. Wilayah Bali Utara yang berada paling jauh dari pusat kota seakan ditinggalkan begitu saja semenjak berpindahnya ibukota Bali dari kota Singaraja menjadi Denpasar.

Berkembangnya teknologi yang semakin pesat, pariwisata tidak hanya dapat diketahui melalui surat kabar, brosur ataupun majalah. Namun dapat diketahui melalui akses internet melalui web atau mobile. Dalam persoalan yang ada saat ini adalah pengoptimalan pemanfaatan teknologi mobile dalam aplikasi kepariwisataan belum dijalankan secara optimal dan dalam pencarian informasi masih belum menyajikan data-data yang lengkap dan memadai terutama informasi yang berhubungan dengan objek pariwisata beserta fasilitas-fasilitas umum terdekatnya. Oleh karena itu pemanfaatan teknologi mobile yang menekankan pada informasi pariwisata, sebagai panduan dan landasan dalam pengembangan pariwisata di Bali Utara merupakan hal yang harus diperhatikan. Perkembangan teknologi informasi melalui mobile di era ini dikarenakan banyak orang membutuhkan suatu sistem informasi yang mudah diakses serta bisa dibawa kemana-mana. Dengan banyaknya penyebaran teknologi mobile yang ada dan kemudahan yang ditawarkan akan sangat membantu jika para wisatawan dapat mengetahui informasi wisata tentang suatu daerah wisata yang akan dituju.

Gelombang pembangunan akomodasi pariwisata di Bali terlihat pesat pasca studi masterplan pariwisata Bali oleh SCETO. Kebijakan yang diterapkan berdasarkan studi tersebut memang terbukti mampu meningkatkan kedatangan pariwisata secara signifikan dari tahun ke tahun. Konsekuensinya daerah kawasan segitiga emas (Badung, Gianyar dan Tabanan) tersebut mulai dipadati dengan investasi. Terjadi penumpukan pembangunan fasilitas pariwisata di daerah tersebut menyebabkan kepadatan penduduk serta kemacetan dimana-mana, sehingga membuat dampak yang tidak baik bagi dunia pariwisata ke depan. Sebaliknya, Kabupaten Buleleng yang memiliki wilayah paling luas diantara kabupaten-kabupaten yang lain di Bali mendapat kunjungan wisatawan yang masih rendah. Data dinas pariwisata provinsi Bali 2011 diperoleh bahwa Kabupaten Buleleng selama lima tahun terakhir memiliki tingkat kunjungan wisatawan yang lebih rendah dibandingkan dengan Kota Denpasar dan Kabupaten Gianyar. Padahal dari segi jumlah dan nilai, Kabupaten Buleleng memiliki Daya Tarik Wisata (DTW) yang paling banyak (38 DTW) dibandingkan dengan Kota Denpasar (13 DTW) dan Kabupaten Gianyar (16 DTW). Kalau ketimpangan pembangunan pariwisata ini dibiarkan tentu akan membawa dampakdampak negatif terhadap pariwisata Bali. Pujaastawa, et al (2005:4) mengemukakan dampak-dampak negatif tersebut berupa makin meningkatnya kesenjangan ekonomi antara Bali Selatan dengan wilayah Bali lainnya, kepadatan penduduk, persaingan hidup serta ancaman terhadap lingkungan. 
Adapun upaya yang dilakukan untuk mendukung percepatan pembangunan pariwisata adalah dengan mengintegrasikan bisnis pariwisata dan teknologi menjadi satu dengan harapan dapat menunjang dan bersinegi utuh. Hal ini memunculkan perlunya berbagai macam sarana promosi tempat-tempat pariwisata di Kabupaten Buleleng, salah satunya dengan sarana internet mobile. Dengan teknologi ini diharapkan dapat memperlihatkan kepada banyak orang, terutama para wisatawan sisi lain dari Pulau Bali, keindahan yang belum terpublikasikan dengan baik karena pemerintah yang masih terfokus kepada apa yang sudah dikenal oleh masyarakat dunia. Melalui sistem yang terintegrasi ini diharapkan dapat membuka wawasan masyarakat/wisatawan bahwa Bali juga memiliki daerah utara yang indah. Mengubah pikiran wisatawan untuk dapat melihat keindahan yang tersembunyi di wilayah Bali Utara dengan cara mengeksplorasi alam.

Selain itu dengan adanya promosi ini, dapat meremajakan kembali citra pulau Bali di mata Internasional dengan berbagai hal baru yang terdapat di wilayah utara, dan tentunya diharapkan melalui publikasi ini dapat meningkatkan jumlah kunjungan wisata dan juga investor untuk membangun wilayah Bali Utara menjadi Bali yang berbeda dengan wilayah di selatan Bali. Menjadikan wilayah Bali Utara sebagai masa depan Bali.

Tentu dengan semakin dikenalnya wilayah Bali Utara, hal ini dapat membantu pemerataan jumlah kunjungan wisatawan di Pulau Bali, sehingga hal ini dapat menguntungkan masyarakat di wilayah Bali Utara, dan juga bisa membantu memecahkan permasalahan kepadatan aktivitas di wilayah Bali selatan. Menjadikan Bali tetap sebagai pulau yang indah dan mempesona.

Tujuan khusus yang ingin dicapai dalam penelitian ini adalah Mengembangkan sebuah sistem informasi yang terintegrasi untuk panduan pariwisata berbasis mobile sebagai daya dukung dalam meningkatkan pariwisata di Kabupaten Buleleng.

Manfaat yang akan diperoleh dalam penelitian ini adalah (i) Mendukung upaya pemerintah daerah dalam mempromosikan objek wisata yang dimiliki oleh pemerintah kabupaten Buleleng, (ii) Meningkatkan daya saing daerah pariwisata kabupaten Buleleng dengan daerah lainnya, (iii) Meningkatkan jumlah kunjungan wisatawan yang berkunjung ke kabupaten Buleleng, (iv)Memberikan kontribusi positif dalam peningkatan pendapatan baik pemerintah daerah maupun warga setempat (v) Memberikan pelayanan informasi maksimal kepada para wisatawan yang berkunjung ke Buleleng dan (vi) Meningkatnya citra daerah sebagai daerah tujuan pariwisata berkelas dunia.

Mobile dapat diartikan sebagai perpindahan yang mudah dari satu tempat ke tempat lain. Phone berasal dari bahasa Inggris yang berarti telepon. Mobile Phone adalah terminal telepon yang dapat berpindah dengan mudah dari satu tempat ke tempat yang lain tanpa terjadinya pemutusan atau terputusnya komunikasi (Silalahi, 2002). Nama lain dari Mobile Phone adalah Telepon Seluler (ponsel) dan Hand Phone (HP). Java adalah sebuah bahasa pemrograman yang dikembangkan oleh Sun Microsystem yang mempunyai kebebasan platform, sehingga bisa dijalankan baik di komputer server, komputer dekstop maupun peralatan yang mempunyai memori kecil seperti handphone, Personal Digital Assistance (PDA) dan sebagainya. Sehingga Java Mobile Phone adalah Mobile Phone yang bisa support dengan teknologi Java. Ketika teknologi Java diperkenalkan pada lingkungan yang begitu tidak stabil ini, sedikit demi sedikit batasan - batasan dari aplikasi berbasis browser pada perangkat komunikasi bergerak dapat diatasi. Di samping berkurangnya latensi selama koneksi antara perangkat keras di sisi server, tampilan layar perangkat komunikasi user juga semakin diperkaya dengan 
animasi - animasi grafis yang menarik, interaksi user dengan sistem semakin meningkat dan sebagainya (Suparno, 2005).

Konten pembelajaran dalam $m$-learning memiliki jenis bermacam-macam. Konten sangat terkait dengan kemampuan device untuk menampilkan atau enjalankannya. Keragaman jenis konten ini mengharuskan pengembang untuk membuat kontenkonten yang tepat dan sesuai dengan karakteristik device maupun pengguna. (1)Teks, Kebanyakan device saat ini telah mendukung penggunaan teks. Hampir semua telepon seluler yang beredar saat ini telah mendukung penggunaan SMS. Kebutuhan memori yang relatif kecil memuat konten berbasis teks lebih mudah diimplementasikan. Namun, keterbatasan jumlah karakter yang dapat ditampilkan harus menjadi pertimbangan dalam menampilkan konten pembelajaran sehingga perlu strategi khusus agar konten pembelajaran dapat disampaikan secara tepat dan efektif meskipun dengan keterbatasan ini. Salah satu contoh aplikasi pembelajaran berbasis teks/SMS adalah Mobile School Service (MSS) yang dikembangkan di University of Novi Sad, Zrenjanin, Serbia.(2)Gambar, Device bergerak yang ada sekarang telah banyak mendukung pemakaian gambar. Kualitas gambar yang dapat ditampilkan dapat beragam dari tipe monokrom sampai gambar berwarna berkualitas tinggi tergantung kemampuan device. File gambar yang didukung oleh device umumnya bertipe PNG, GIF, JPG. Ukuran gambar yang bisa ditampilkan pada handphone masih tergantung dari kapasitas memory pada handphone. Penggunaan gambar sebagai konten pembelajaran biasanya digabungkan dengan konten lain, misalnya teks, audio, dan video (Wirawan.,2008).(3)Audio, Banyak perangkat bergerak saat ini telah mendukung penggunaan audio. Beberapa tipe file yang biasanya digunakan di lingkungan device bergerak antara lain rm, mp3, amr dan lain-lain. Oleh karena file audio biasanya memiliki ukuran yang cukup besar, menyebabkan file audio tersebut harus diolah terlebih dahulu sehingga dapat digunakan di lingkungan device bergerak yang memiliki kapasitas memori yang relatif kecil. (4)Video, Meski dalam kualitas dan ukuran yang terbatas, beberapa tipe device bergerak telah mampu memainkan file video. Format file yang didukung oleh device bergerak antara lain adalah 3gp, MPEG, MP4, dan lain-lain. Sama seperti file audio, kebanyakan file video memiliki ukuran yang cukup besar sehingga harus dikonversi dan disesuaikan dengan keterbatasan device. (5) Aplikasi Perangkat Lunak, Konten yang cukup menarik pada aplikasi mobile adalah aplikasi perangkat lunak yang dipasang pada device dapat dikostumisasi sesuai kebutuhan sehingga akan lebih mudah dan intuitif untuk digunakan. Aplikasi mobile ini juga mampu menggabungkan konten-konten lain seperti teks, audio dan video sehingga menjadi lebih interaktif. Jenis aplikasi yang saat ini banyak digunakan antara lain aplikasi berbasis WAP/WML, J2ME, dan aplikasi lainnya. Salah satu contohnya adalah aplikasi mobile yang dikembangkan dalam penelitian yaitu Pengembangan Rancangan Mobile Phone Based Learning pada Materi Basic SQL mata kuliah Basis Data Lanjut (Wirawan, 2011). Media pembelajaran yang dikembangkan menggabungkan beberapa konten teks dan gambar. Media ini digunakan sebagai sarana pembelajaran pada materi Basic SQL mata kuliah Basis Data Lanjut, dimana pebelajar dapat melakukan proses belajar dimana saja dan kapan saja. Contoh media pembelajaran yang dikembangkan oleh peneliti.

\section{METODE}

Metode yang digunakan dalam penelitian ini adalah metode penelitian pengembangan (research and development), dimana desain pengembangan yang dipilih adalah menggunakan Model Dick \& Carey (1990). 
Karena luaran utama yang akan dihasilkan dalam penelitian berupa sebuah perangkat lunak, maka dalam proses pengembangan sistem akan dilengkapi dengan metode khusus pengembangan perangkat lunak dengan menggunakan metode Software Development Life Cycle (SDLC) dengan Waterfall-based Model.

Agar dapat divalidasi secara akademik dan ilmiah, produk perangkat lunak yang dihasilkan dari proses pengembangan ini akan divalidasi dan diuji melalui dua tahap pengujian yaitu, (i)Pengujian produk secara teknik (technical test) sebagai sebuah perangkat lunak, dilakukan sesuai dengan prosedur pengujian sebuah perangkat lunak dan juga melalui uji ahli desain (ii) Pengujian sistem di lapangan untuk menguji efektifitas sistem yang telah dikembangkan dengan melihat peningkatan jumlah kunjungan wisatawan dalam kurun waktu tertentu dengan pemanfaatan sistem terintegrasi berbasis mobile

Pengembangan sistem terintegrasi untuk panduan pariwisata berbasis mobile ini dikatakan berhasil jika memenuhi kriteria dihasilkannya sebuah produk berupa sistem terintegrasi untuk panduan pariwisata berbasis mobile yang mendukung peningkatan pariwisata di Kabupaten Buleleng dalam rangka strategi percepatan pembangunan

\section{HASIL DAN PEMBAHASAN}

Dari hasil analisis Kondisi Umum dan kondisi teknis Teknologi Informasi di Dinas Pariwisata Kabupaten Buleleng, diperlukan perangkat lunak yang mampu mengintegrasikan sistem yang telah ada sebelumnya dengan sistem yang akan dikembangkan sebagai panduan pariwisata sehingga mendukung peningkatan pariwisata di Kabupaten Buleleng. Untuk itu dibutuhkanlah sistem yang berbasis web dan berbasis mobile dengan tampilan yang menarik dengan fasilitas informasi yang sesuai dengan kebutuhan wisatawan dan selalu update. Secara teknis, perangkat lunak ini mampu :

1. Menampilkan informasi tempat wisata yang menjadi unggulan di Kabupaten Buleleng

2. Menampilkan informasi hotel (penginapan) yang ada di Kabupaten Buleleng secara detail

3. Menampilkan informasi tempat wisata kuliner yang menjadi trademark diKabupaten Buleleng

4. Menampilkan informasi lokasi pusat oleh-oleh yang ada di Kabupaten Buleleng

5. Menampilkan informasi kerajinan dan kesenian yang menjadi khas masingmasing daerah (desa unggulan) yang ada di Kabupaten Buleleng serta event-event kesenian yang akan diadakan maupun yang sedang berlangsung sehingga dimungkinkan semua kegiatan seni yang diselenggarakan maupun program promosi wisata dari dinas akan lebih langsung ke para wisatawan.

6. Menampilkan informasi tambahan lainnya seperti Lokasi Bank, Money Changer, Apotek, Rumah Sakit, dan SPBU serta lokasi kantor Polisi.

Sesuai dengan tujuan penelitian ini, Sistem Terintegrasi untuk Panduan Pariwisata berbasis mobile sebagai daya dukung pariwisata di Kabupaten Buleleng, diharapkan dapat memberikan infomasi yang update dan detail mengenai daerah pariwisata yang belum tergali dan keindahan yang belum terpublikasikan dengan baik karena pemerintah yang masih terfokus kepada apa yang sudah dikenal oleh masyarakat dunia. Melalui sistem yang terintegrasi ini diharapkan dapat membuka wawasan masyarakat/wisatawan bahwa Bali juga memiliki daerah utara yang indah. Mengubah pikiran wisatawan untuk dapat melihat keindahan yang tersembunyi di wilayah Bali Utara dengan cara mengeksplorasi alam sehingga dengan 
demikian mampu meningkatkan kunjungan wisatawan dan juga investor untuk membangun wilayah Bali Utara menjadi Bali yang berbeda dengan wilayah di selatan Bali.

Perangkat lunak sistem terintegrasi panduan pariwisata ini dikembangkan berbasis web dan berbasis mobile. Pada sistem berbasis web, pengguna (pengunjung) dapat melihat informasi tentang pariwisata yang ada di Kabupaen Buleleng. Selain pengguna, seorang administrator dapat mengatur tampilan dan isi dari web tersebut. Pada sistem berbasis mobile, pengguna dapat juga mengakses informasi-informasi pariwisata. Kedua sistem ini merupakan sistem terpadu yang saling terkait. Grand arsitektur sistem dapat ditunjukkan pada Gambar 1.

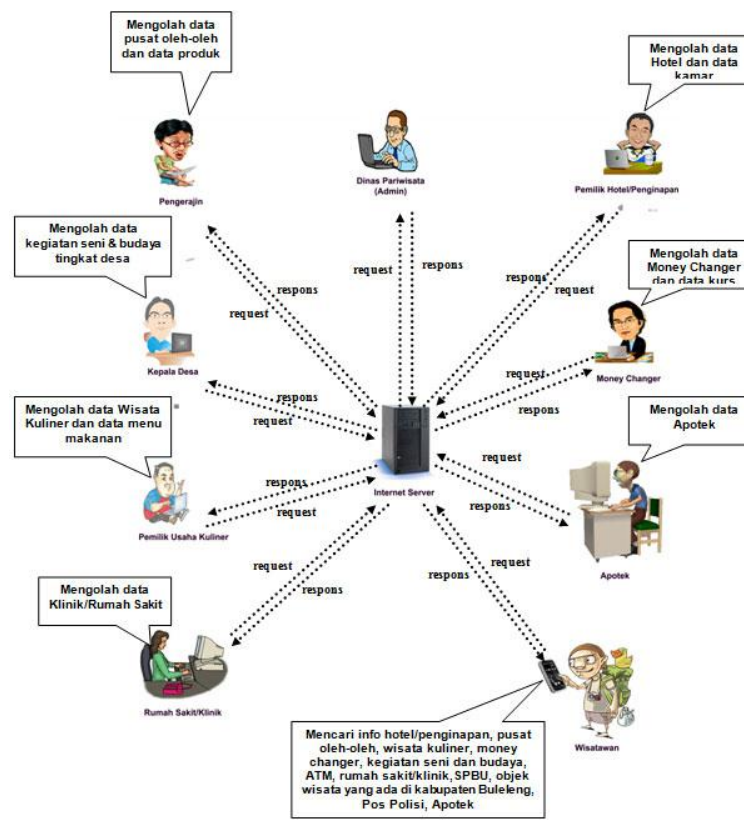

Gambar 1. Grand Arsitektur Pengembangan sistem terintegrasi panduan Pariwisata

Model fungsional perangkat lunak memberikan gambaran umum mengenai proses-proses yang terjadi dalam perangkat lunak tanpa memberikan detail mengenai bagaimana proses-proses tersebut diimplementasikan. Model fungsional juga memberikan gambaran tentang aliran data yang terjadi antar proses-proses yang ada maupun antar proses dengan entitas luar, misalnya pengguna perangkat lunak. Aliran data tersebut akan mendeflnisikan masukan dan keluaran yang terdapat pada masingmasing proses yang terjadi, sehingga hubungan antar proses dapat terlihat dengan jelas. Model fungsional yang akan digunakan untuk mendeskripsikan perangkat lunak ini adalah Data Flow Diagram (DFD).

Diagram konteks merupakan DFD level 0 dari perangkat lunak. Pada diagram konteks tersebut dapat dilihat interaksi yang terjadi antara pengguna dengan perangkat lunak. Gambar 2 merupakan Diagram Konteks atau DFD level 0 dari Sistem Terintegrasi Panduan Pariwisata berbasis Mobile yang dikembangkan.

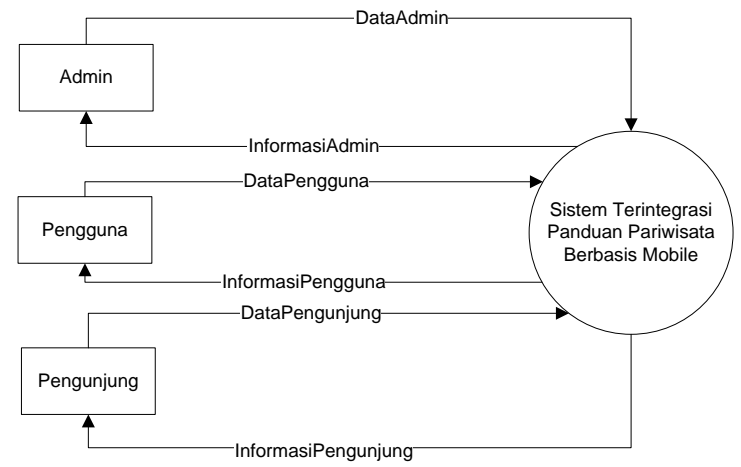

Gambar 2. Diagram Konteks/ DFD Level 0 Perangkat Lunak

Pada gambar DFD level 0 Sistem Terintegrasi Panduan Pariwisata Berbasis Mobile terdapat 3 buah pihak eksternal yaitu admin, pengguna dan pengunjung. Admin merupakan pihak eksternal yang memiliki hak penuh untuk melakukan perubahan terhadap konten dari keseluruhan sistem. Pihak ekternal pengguna merupakan pihak yang dapat melakukan perubahan konten hanya pada hal-hal yang terkait dengan 
pihak pengguna, misalnya pemilik hotel dapat menambahkan atau mengurangi isi konten hotel terkait. Pihak eksternal pengunjung merupakan pihak yang hanya dapat melihat isi dari informasi pariwisata tanpa dapat merubah isi kontennya.

Diagram Konteks atau DFD Level 0 tersebut selanjutnya dipecah lagi menjadi beberapa proses dalam DFD Level 1 seperti Gambar 3.

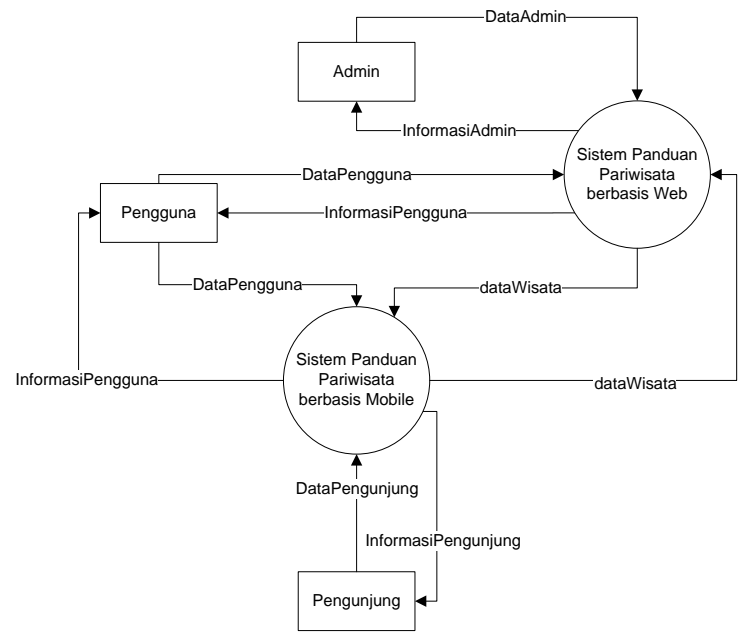

Gambar 3. DFD Level 1 Perangkat Lunak Pada Gambar 3 diperlihatkan bahwa terdapat 2 sistem yang membangun sistem ini, yaitu Sistem Panduan Pariwisata berbasis web dan Sistem Panduan Pariwisata Berbasis Mobile. Sistem Web merupakan sistem berbasis web yang dapat menampilkan informasi tentang pariwisata dan untuk mengatur isi dari informasi pariwisata. Sistem Panduan Pariwisata Berbasis Mobile merupakan sistem yang terhubung dengan Sistem Web yang digunakan untuk menampilkan informasi pariwisata dalam perangkat mobile.

Perancangan perangkat lunak yang akan dilakukan meliputi perancangan struktur menu, serta perancangan layar antarmuka Struktur Menu dan arsitektur dari perangkat lunak ini adalah seperti gambar 4 ,.

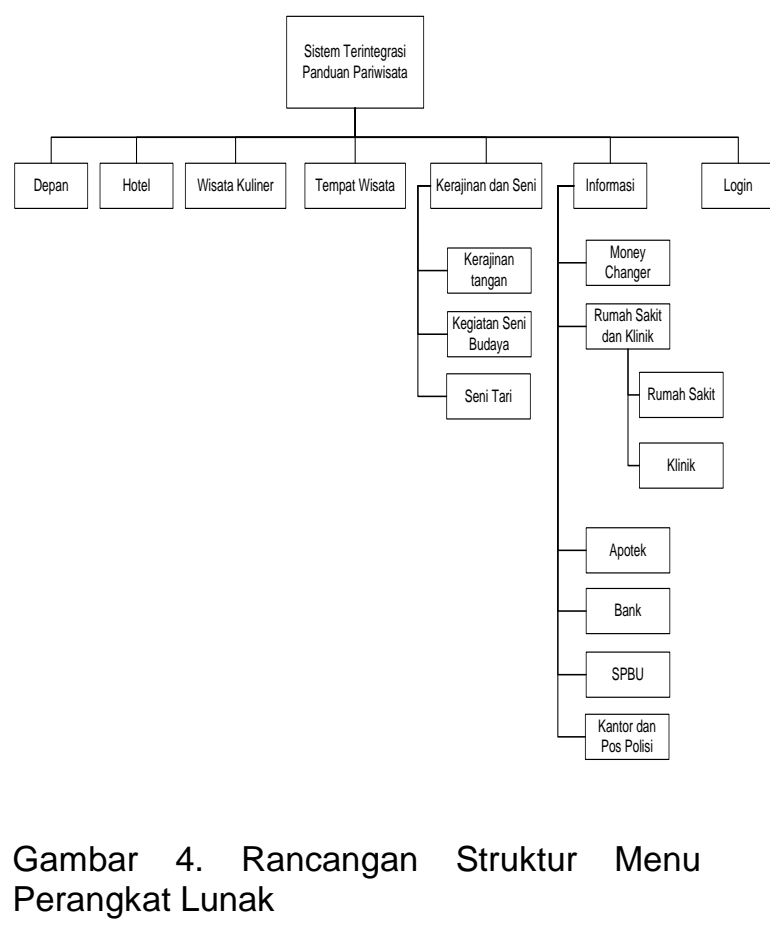

Rancangan layar antarmuka perangkat lunak ini diimplementasikan dengan menggunakan halaman-halaman web pada lingkungan implementasi web browser. Implementasi rancangan layar utama antarmuka perangkat lunak di web dan mobile dapat dilihat pada gambar $5,6,7$, dan 8. 


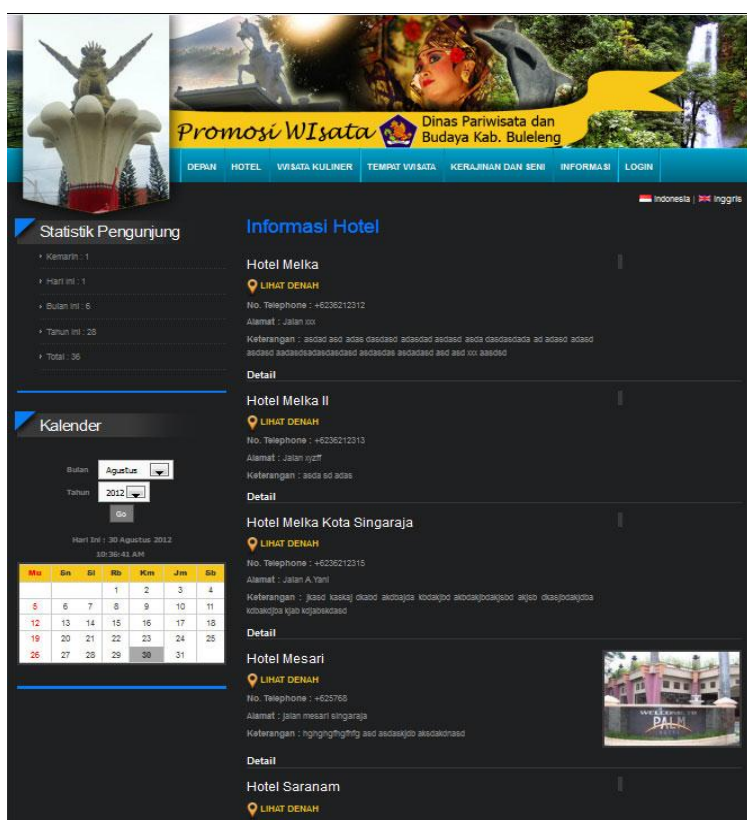

Gambar 5. Layar antarmuka menu informasi hotel padaWeb

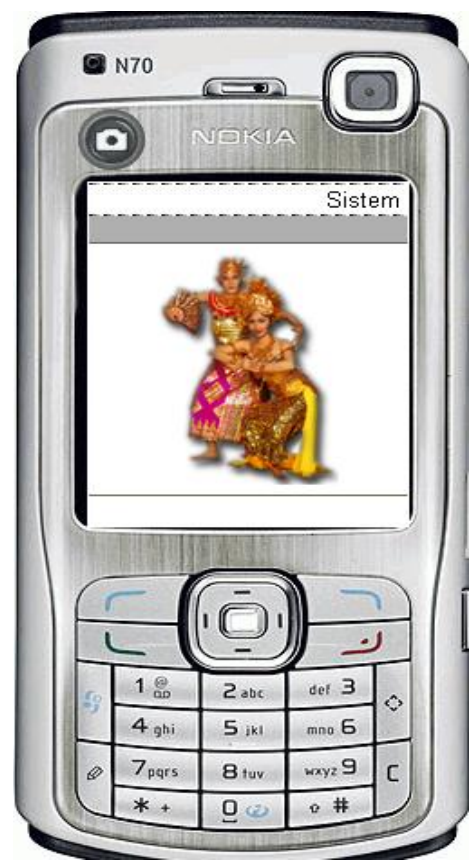

Gambar 6. Layar antar muka mobile

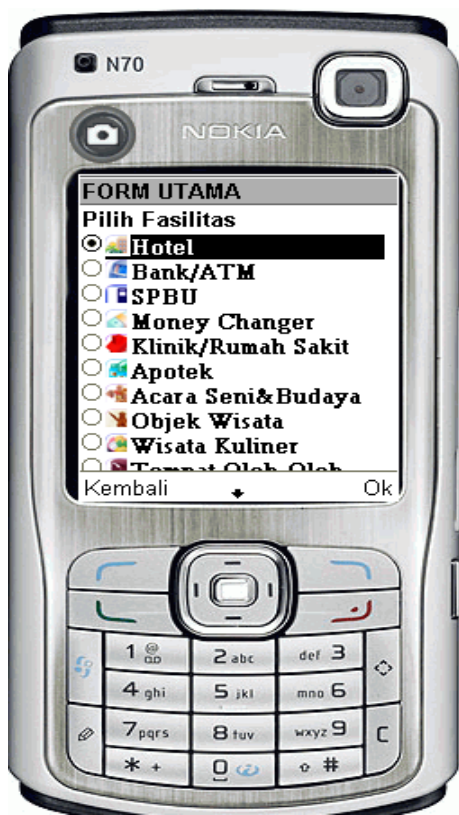

Gambar 7. Tampilan pilih fasilitas

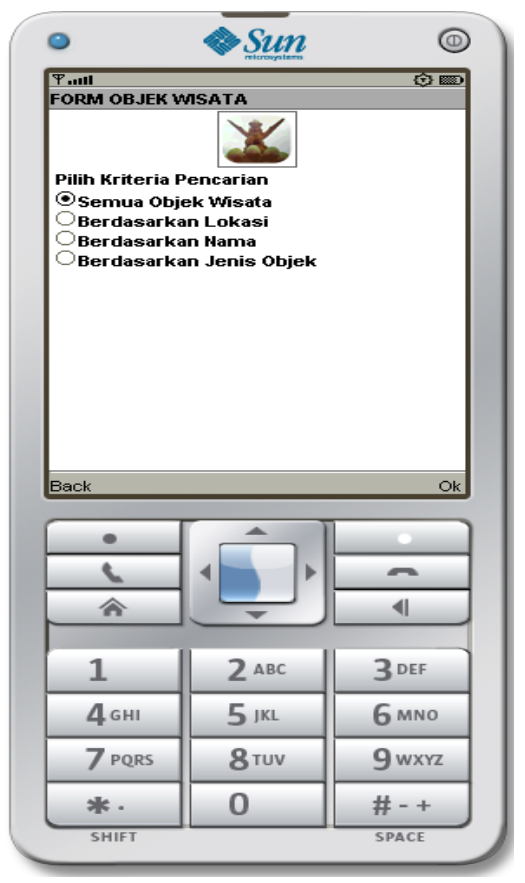

Gambar 8. Tampilan form obyek wisata

Jurnal Sains dan Teknologi $\mid 260$ 
Aplikasi Sistem Terintegrasi Panduan Pariwisata berbasis Mobile merupakan aplikasi yang memberikan informasi kepada pengguna info-info daerah yang menjadi tujuan wisata di Kabupaten Buleleng lengkap dengan segala fasilitas umum terdekatnya. Info-info tersebut diantaranya Obyek wisata, Hotel, kegiatan seni dan budaya, kerajinan, kuliner khas Kabupaten Buleleng, Money changer, Bank, ATM, Post Polisi, Klinik dan Rumah Sakit, Apotek hingga SPBU. Semua disampaikan secara detail dalam sistem ini sebagai salah satu upaya untuk mendukung pembangunan pariwisata di Kabupaten Buleleng.

Sistem ini terhubung ke dalam dua sisi yaitu sisi server dan client. Dalam sisi Server berada pada lingkungan web (http://www.wisata-singaraja.com)

sedangkan client berada dalam lingkungan mobile. Pada Saat aplikasi telah terinstall di handset mobile (HP) dengan Sistem Operasi BADA atau Android, Aplikasi akan muncul dengan jelas. Namun apabila menggunakan Sistem Operasi Symbian, tampilan text pada HP terlihat masih belum rapi. Ini disebabkan karena keterbatasan ukuran layar dan kemampuan sistem yang belum mampu mengatur teks yang melebihi lebar layar.

Saat pengguna membuka aplikasi, akan muncul splashscreen atau layar pembuka sekitar 3 detik. Setelah tampil splashscreen, pengguna akan diminta untuk memilih bahasa yang digunakan. Terdapat dua pililhan bahasa yang disediakan, yaitu bahasa Indonesa dan Inggris. Menu utama aplikasi akan muncul setelah bahasa yang digunakan pada sistem dipilih. Menu-menu utama yang muncul akan disesuaikan dengan bahasa yang terpilih. Pengguna dapat memilih menu utama yang terdiri dari menu Hotel, Bank/ATM, SPBU, Money Changer, Klinik/Rumah Sakit, Apotek, Acara Seni \& Budaya, Objek Wisata, Wisata Kuliner, Tempat Oleh-Oleh, Kantor Polisi. Secara umum aplikasi dapat menampilkan informasi umum dan informasi detail dari masing-masing menu utama. Pengguna memerlukan akses pertukaran data dari mobile device ke server saat pengguna ingin mendapatkan informasi umum maupun informasi khusus. Sebagai contoh ketika pengguna memiliih menu Hotel, maka pengguna akan diminta untuk memilih kriteria pencarian hotel berdasarkan kriteria semua hotel, lokasi, harga nama. Setelah dilakukan pemilihan kriteria pencarian, sistem akan menampilkan daftar hotel yang masuk dalam kriteria pencarian. Ketika salah satu Hotel dipilih maka akan ditampilkan informasi umum dari hotel tersebut dan menu untuk menampilkan informasi detail. Informasi detail yang bisa dipilih yaitu kamar dan denah lokasi. Pada menu kamar akan ditampilkan menu kamarkamar yang disediakan pada hotel tersebut (Ekonomi, VIP, VVIP). Masing-masing kamar dapat dilihat informasi dan gambar kamarnya. Selain informasi kamar, pada informasi detail juga ditampilkan denah lokasi dari hotel tersebut. Proses yang sama juga dapat dilakukan pada menu utama yang lainnya (Bank/ATM, SPBU, Money Changer, Klinik/Rumah Sakit, Apotek, Acara Seni \& Budaya, Objek Wisata, Wisata Kuliner, Tempat Oleh-Oleh, Kantor Polisi). Untuk keluar dari sistem, tombol kembali pada bagian kanan bawah dapat dipilih sampai pada menu pemilihan bahasa kemudian pilih menu exit. Setelah dipilih menu exit, maka sistem akan ditutup.

\section{SIMPULAN DAN SARAN}

Berdasarkan hasil pengembangan dan pengujian fungsional sistem terintegrasi panduan pariwisata berbasis mobile yang telah dilakukan, dapat disimpulkan bahwa Aplikasi sistem terintegrasi panduan pariwisata berbasis mobile dapat menjalankan fungsionalitas yang dibutuhkan dalam mencari info-info daerah pariwisata di Kabupaten Buleleng secara detail, beserta fasilitas umum terdekatnya.

Saran-saran yang dapat diberikan, Pengembangan sistem terintegrasi panduan 
pariwisata berbasis mobile ini kedepannya agar lebih bervariasi bidang pengembangannya juga dari segi fiturfiturnya seperti push service sehingga pengguna tidak merasa bosan dalam menggunakan aplikasi ini. Perlu ditambahkan fasilitas Global Positioning System (GPS) sehingga pengguna mendapatkan informasi mengenai lokasi fasilitas umum terdekat dari current posisi pengguna.

\section{DAFTAR PUSTAKA}

Andri, 2011, Perancangan dan Implementasi Aplikasi Mobile Bandung Guidance Berbasis Teknologi Location Based Service Menggunakan Platform BlackBerry, http:// courseware.politekniktelkom.ac.id/ Jurnal\%20Proyek\%20Akhir/TK/Jur nal\%20Andri.pdf diakses tanggal 16 April 2012

Endang, Asdhiana,I.M., 2012, Kunjungan Wisatawan ke Bali Meningkat, http://travel.kompas.com/read/2012/02/1 4/2030325/Kunjungan.Wisatawan.ke.Bal i.Meningkat (diakses tanggal 15 April 2012)

Hutabarat,M.D., 2010, Analisis Pengetahuan Tentang Objek Wisata Dan Minat Wisatawan Jerman Berkunjung $\mathrm{Ke}$ Indonesia, Jurnal Penelitian Pendidikan Vol. 11 No. 1 April 2010, http://jurnal.upi.edu/file/ Mery_Dahlia_11.pdf (diakses tanggal 15 Aparil 2012)
Muh Tamimuddin $\mathrm{H} ; \quad$ Proceeding Perancangan Aplikasi M-Learning Berbasis Java,2006

Raharjo, B., Heryanto, I., dan Haryono,A., 2007, Tuntunan Pemrograman Java Untuk Handphone, Informatika, Bandung

Suparno, 2005, Implementasi Java Mobile Phone Via GPRS untuk Sistem Akses Informasi Akademik Fakultas MIPA Universitas Gadjah Mada, FMIPA Universitas Gadjah Mada, Yogyakarta.

Wirawan, Development Learning Media for Mobile Phone Based Materials Basic SQL Syntax in Subjects Advanced Database (Case Study on IT Educational Programs Semester III) ;2011; Prosiding Seminar Internasional Teknologi Informasi dan Pendidikan, Bridging ICT and Education, ISSN 19073739,DIN EN ISO 9001:2008, Cert. No.01 100 086042, Fakultas Teknik Universitas Negeri Padang

Wirawan, Sistem Pencatatan Perkembangan Pasien Berbasis Mobile Phone;2010; Prosiding Senapati 2010

Wicaksono, A, 2002, Pemrograman Aplikasi Wireless dengan Java, Elex Media Komputindo, Jakarta.

Website dinas Kebudayaan dan Pariwisata Kabupaten Buleleng, http://disbudpar. bulelengkab.go.id/, diakses tgl 15 April 2012 